\author{
Jarosław Firlit ${ }^{\star}$ \\ ORCID: 0000-0002-0249-1742 \\ Uniwersytet Wrocławski
}

DOI: $10.19195 / 1733-5779.26 .2$

\title{
Odwrócona hipoteka produktem przeznaczonym dla „srebrnego rynku”
}

JEL Classification: K39, O16

Slowa kluczowe: odwrócona hipoteka, srebrna gospodarka, dożywotnie użytkowanie nieruchomości, sektor nieruchomości mieszkaniowych, transakcje nieruchomościami

Keywords: reverse mortgage, silver economy, equity release, life estate, residential sector, real estate transactions

Abstrakt: Opracowanie jest przedstawieniem problematyki odwróconej hipoteki jako produktu przeznaczonego dla „srebrnego rynku”. Z uwagi na charakter referatu główną metodą badawczą będzie obiektywna analiza przepisów prawnych związanych z odwróconym kredytem hipotecznym, a także krytyczna analiza porównawcza literatury i elementów ekonomicznych związanych z produktem finansowym, jakim jest odwrócona hipoteka. Przy odpowiedniej analizie i zrozumieniu opisanych czynników i umiejętnym ich przełożeniu na praktyczne zasady funkcjonowania rynku można przewidzieć nadchodzący trend panujący w gospodarce wolnorynkowej podczas realizacji odwróconego kredytu hipotecznego.

\section{Equity release dedicated product for the "silver economy"}

Abstract: The presented study shows the problem of reverse mortgage as a dedicated product for the "silver market". Due to the nature of the paper, the main research method will be an objective analysis of legal provisions related to the reverse mortgage loan as well as a critical comparative analysis of literature and economic elements related to the financial product that is a reverse mortgage. With proper analysis and understanding of the above-described factors and their ability to translate them into practical principles of market functioning, we are able to predict the upcoming trend in the free market economy during the implementation of the reverse mortgage loan.

\footnotetext{
* Opiekun naukowy (Scientific Tutor) — Józef Frąckowiak
} 


\section{Wstęp}

Seniorzy posiadający zasób majątkowy w formie własności nieruchomości, prawa uży tkowania wieczystego lub spółdzielczego własnościowego prawa do lokalu mają możliwości uzyskiwania dodatkowego źródła przychodów finansowych z tytułu odwróconej hipoteki.

Dzisiaj podmioty oferujące tego typu produkt możemy podzielić na dwie grupy. Pierwsza to banki, które przy udzielaniu odwróconego kredytu hipotecznego są związane przepisami ustawy o odwróconym kredycie hipotecznym ${ }^{1}$ i tylko one jako instytucje finansowe mogą oferować odwrócony kredyt hipoteczny. Drugim podmiotem oferującym odwróconą hipotekę są Fundusze Inwestycyjne (Fundusze Hipoteczne), które oferują ten produkt na podstawie zawartej umowy pożyczki, sprzedaży lub renty zgodnie z regulacjami kodeksu cywilnego i nie podlegają pod przepisy ustawy o odwróconym kredycie hipotecznym.

Rosnąca przeciętna długość życia Polaków oraz niepewność co do wysokości świadczeń emerytalnych mogą być zachętą dla starszych osób do korzystania z odwróconego kredytu hipotecznego. W związku z tym ważne jest zapewnienie regulacji prawnych pozwalających na bezpieczne funkcjonowanie tego rodzaju ofert. Uchwalenie w październiku 2014 roku ustawy o odwróconym kredycie hipotecznym uregulowało jedynie najistotniejsze elementy tej usługi, pozostawiając wiele kwestii do ustalenia między stronami w umowie ${ }^{2}$.

Uchwalenie ustawy o odwróconym kredycie hipotecznym jest reakcją naszego ustawodawcy na istotną potrzebę społeczną uruchomienia kapitału rzeczowego zawierającego się w nieruchomościach (ang. equity release) ${ }^{3}$.

Odwrócony kredyt hipoteczny (ang. reverse mortgage) — jest połączeniem kredytu hipotecznego oraz renty dożywotniej. Może być wypłacany w formie dożywotniej renty, jednorazowej wypłaty ustalonej kwoty, linii kredytowej z ustalonym limitem lub w innej formie będącej kombinacją trzech wymienionych rozwiązań ${ }^{4}$.

Potrzeba ta jest odczuwana zwłaszcza przez osoby starsze, które dysponują prawami rzeczowymi do nieruchomości i jednocześnie cierpią na niedostatek środków pieniężnych na bieżące utrzymanie. Dotychczas brakowało wyspecjalizowanego mechanizmu prawnego pozwalającego na przekształcenie tego rodzaju niepłynnego kapitału rzeczowego w strumień płynnych środków pieniężnych. Bezpośrednim impulsem do uchwalenia ustawy o odwróconym kredycie hipotecznym były sygnały o nieprawidłowościach w obrocie gospodarczym, w szczegól-

${ }^{1}$ Ustawa z dnia 23 października 2014 roku o odwróconym kredycie hipotecznym, tekst jedn. z dnia 6 czerwca 2016 roku, Dz.U.2016.786.

2 M. Grzeszczuk-Gniewek, Odwrócony kredyt hipoteczny, „Państwo i Społeczeństwo” 2, ma-rzec-kwiecień 2015, s. 307.

3 T. Czech, Odwrócony kredyt hipoteczny. Komentarz, LEX, 2015.

4 A. Szelągowska, Wspótczesna bankowość hipoteczna, Warszawa 2010, s. 85-86. 
ności wykorzystywaniu przez niektórych przedsiębiorców łatwowierności i nieporadności osób starszych w celu przejmowania wartościowych nieruchomości ${ }^{5}$.

Mając to na względzie, do celu niniejszego opracowania nie będzie należało przeprowadzenie szczegółowej analizy, ryzyka, które ponosi instytucja finansowa czy też wskazanie rozwiązań prawnych, lecz ukazanie szans, zagrożeń i niebezpieczeństwa, jakie może nieść z sobą ten produkt finansowy, oferowany przez fundusze ich potencjalnych beneficjentów, którzy de facto są seniorami, a także na kwestie ekonomiczne związane z tym produktem.

Z uwagi na charakter niniejszej pracy główną metodą badawczą będzie obiektywna analiza przepisów prawnych związanych z odwróconym kredytem hipotecznym, a także krytyczna analiza porównawcza literatury i elementów ekonomicznych związanych z produktem finansowym, jakim jest odwrócona hipoteka. W niniejszym artykule ustawowy termin ,odwrócony kredyt hipoteczny” będzie stosowany zamiennie z terminem ,odwrócona hipoteka”.

\section{Determinanty „srebrnego rynku”}

Konstrukt pojęciowy srebrnej gospodarki nie ma odniesienia w realiach, jest pewną abstrakcją, która ma za zadanie uzmysłowić skalę przemian społeczno-gospodarczych wywołanych starzeniem się demograficznym oraz związanych z tym możliwości i ograniczeń rozwoju systemów gospodarczych. Stwarza nową szansę radzenia sobie z problemami starzenia się społeczeństw na podstawie proaktywnego podejścia do gospodarki napędzanej produkcją towarów i usług generowanych potrzebami starzejących się populacji. Tradycyjne podejście wymusza na decydentach jedynie bierne asygnowanie środków, nowe ujęcie zaś akcentuje możliwość kreatywnego tworzenia nowych wartości pod wpływem zachodzących procesów starzenia się demograficznego 6 .

Pojawienie się srebrnej gospodarki wiąże się z jej celowym kształtowaniem, zainspirowanym różnorodnymi potrzebami ludzi starszych, produkcją tego, co niezbędne, a także dóbr i usług luksusowych — czas wolny pozostający do dyspozycji osób starszych i stopień zamożności starzejących się pokoleń mogą być w tym względzie sprzymierzeńcem. W pierwszym przypadku mamy do czynienia z gospodarką senioralną na pierwszym etapie rozwoju. Drugi etap gospodarki senioralnej pojawia się wówczas, gdy następuje zmiana z podejścia reaktywnego na proaktywne w związku z podejmowaniem działań wyprzedzających wystąpienie niekorzystnych konsekwencji starzenia się ludności?

5 M. Bączyk, Umowy w zakresie czynności bankowych, [w:] System prawa handlowego, t. 5. Prawo umów handlowych, red. S. Włodyka, Warszawa, 2014, s. 1021.

${ }^{6}$ B. Urbaniak et al., Socjoekonomika starzenia się współczesnych społeczeństw, Warszawa 2015, s. 91.

7 P. Szukalski, Solidarność pokoleń. Dylematy relacji międzypokoleniowych, Łódź 2012, s. 108. 
Podstawowy problem z jednoznacznym ustaleniem wieku, od którego zaczyna się starość, polega na tym, że wiek metrykalny (zwany niekiedy chronologicznym lub kalendarzowym) nie pokrywa się w indywidualnych przypadkach z wiekiem biologicznym (wyznaczanym stopniem zużycia organizmu, przejawiającym się najpełniej w spadku odporności na niekorzystne czynniki zewnętrzne), wiekiem czynnościowym (zwanym niekiedy funkcjonalnym, określającym stan sprawności intelektualnej i motorycznej) i wiekiem społecznym (wyznaczonym przez wypełniane w danej społeczności role społeczne). Dlatego też najczęściej odwołujemy się do granic istniejących w systemie prawnym, granic odzwierciedlających jedynie pośrednio społeczne odczucia odnośnie do początku starości ${ }^{8}$.

Konsekwencje procesu starzenia się ludności są nierozerwalnie związane z sytuacją gospodarczą państw, które już zmagają się z tym problemem (przykładem może być Japonia) lub w przyszłości, w perspektywie kilkunastu lub kilkudziesięciu lat, będą zmuszone do przedsięwzięcia działań mających na celu niwelowanie skutków negatywnych zjawisk demograficznych. W tle dyskursu, jaki prowadzony jest już od dłuższego czasu również w skali globalnej, zrodziła się koncepcja „srebrnej gospodarki" (silver economy) zwracająca uwagę na potrzebę wykorzystania wzrostu udziału osób starszych w populacji, ogółem do ukierunkowania rozwoju państw w taki sposób, aby wspomniane zagrożenie stało się szansą. Zgodnie ze wskazaną ideą do osiągnięcia korzyści wynikających ze starzenia się społeczeństwa konieczne jest zauważenie, że za zmianą struktury wieku ludności podąża zmiana struktury potrzeb populacji oraz pobudzenie osób po 65. roku życia (tak zwane aktywne starzenie się) do aktywności na różnych płaszczyznach, w tym zawodowej ${ }^{9}$.

Stąd też do pojęcia silver economy należy podchodzić dualnie, z jednej strony jest to bowiem podejście skoncentrowane na potrzebach starszego pokolenia w kontekście potrzeb i popytu, a z drugiej — na wykorzystaniu specyficznych cech ludzi starszych do zwiększenia ich aktywności i wykorzystania ich potencjału ${ }^{10}$.

Koncepcja srebrnej gospodarki dostrzega w niekorzystnych zmianach demograficznych potencjalne źródło wzrostu, a nie jego zagrożenie. Zmiany strukturalne wynikające ze starzenia się traktuje jako innowację. Wymieniane często wyzwania wobec starzenia się populacji muszą być ujęte w strategiach rozwoju gospodarek i regionów. Kryzys demograficzny w Europie może być szansą na stworzenie również w Polsce nowego rodzaju biznesu związanego z usługami opiekuńczymi dla seniorów. Ich realizacja musi szanować wolność i godność osoby oraz uwzględnić odpowiedzialność rodziny i wspólnot społecznych za warunki jej realizacji ${ }^{11}$.

8 P. Szukalski, Ageizm — dyskryminacja ze względu na wiek, [w:] Starzenie się ludności Polski - między demografia a gerontologia społeczna, red. J.T. Kowaleski, P. Szukalski, Łódź 2008, s. $1-2$.

9 S. Golinowska, ,Srebrna gospodarka” i miejsce w niej sektora zdrowotnego. Koncepcja i regionalne przykłady zastosowania, „Zdrowie Publiczne i Zarządzanie” 9, 2011, nr 1, s. 76.

${ }^{10}$ Ibidem, s. 76-85.

11 M. Rudnicka, A. Surdej, Gospodarka senioralna. Nowy sektor gospodarki narodowej w Polsce, Warszawa 2013, s. 4. 
Specjalizacja gospodarek, państw i regionów oznaczająca osiągnięcie umiejętności i biegłości w wytwarzaniu określonych dóbr w pewnych dziedzinach nauki czy technologii była przedmiotem zainteresowania nauk ekonomicznych już od ponad 200 lat. Znajomość teorii handlu zagranicznego, międzynarodowego (poczynając od teorii kosztów absolutnych, komparatywnych, obfitości zasobów itp.) pozwala w pełni zastosować te koncepcje w specjalizacji regionalnej czy krajowej ${ }^{12}$.

W ostatnich latach inteligentna specjalizacja stała się doktryną polityczną. Obecnie jest filarem tak zwanej inicjatywy przewodniej pod nazwą ,unia Innowacji” w ramach strategii „Europa 2020”. Regiony europejskie zostały de facto zmuszone do wskazania swoich tak zwanych inteligentnych specjalizacji pod groźbą zablokowania możliwości korzystania z Europejskiego Funduszu Rozwoju Regionalnego w latach 2014-2020. W Polsce regiony zdefiniowały swoje inteligentne specjalizacje w sposób różnorodny, w procesie tworzenia czy aktualizacji strategii innowacji, czy strategii rozwoju regionalnego. Jeżeli nawet dokonano procedury wyłaniania inteligentnych specjalizacji, to z nikłym udziałem metodyki foresightu i benchmarkingu. A te narzędzia są niezastąpione w typowaniu inteligentnych specjalizacji ${ }^{13}$.

Polska jest jednym z krajów, który boryka się z problemem starzejącego się społeczeństwa - liczba emerytów w 2001 roku oscylowała wokół 4,5 mln osób, tymczasem w pierwszym półroczu 2016 zaczęła zbliżać się do $9 \mathrm{mln}$. Z nową falą emery tów wzrosły również wydatki ZUS. W styczniu 2014 roku ZUS wydawał na emerytury 9,88 mld zł miesięcznie. Rok później już 10,26 mld zł. Te dodatkowe $380 \mathrm{mln}$ zł miesięcznie daje rocznie blisko $4,6 \mathrm{mld} \mathrm{z}^{14}$.

\section{Istota odwróconej hipoteki}

Istnieje kilka sposobów wykorzystania własności nieruchomości w celu zwiększenia swoich bieżących wpływów. Po pierwsze, można posiadaną nieruchomość sprzedać, a z uzyskanych środków zakupić tańszą (na przykład mniejszą lub zlokalizowaną w mniej atrakcyjnej okolicy niż poprzednia), a z reszty środków finansować bieżące wydatki. Można także zrezygnować z kupna innej nieruchomości i ograniczyć się wyłącznie do wynajmu lokalu mieszkalnego. Rozwiązaniem podobnym jest sprzedaż nieruchomości, a następnie wynajęcie jej od nabywcy (zaletą jest to, że zbywca nadal może zamieszkiwać tę samą nieruchomość). Drugim rozwiązaniem jest wynajęcie części nieruchomości, które pozwoli osiągnąć dodatkowe środki bez konieczności sprzedaży nieruchomości ${ }^{15}$.

12 M. Kardas, Inteligentne specjalizacje - (nowa) koncepcja polityki innowacyjnej, „Optimum. Studia Ekonomiczne" 2001, nr 2 (50), s. 122-124.

13 Ł. Nazarko, Inteligentne specjalizacje polskich regionów - przyczynek do ewaluacji, „Przedsiębiorczość i Zarządzanie” 15, 2014, z. 8, cz. 1, s. 247-260.

$14 \mathrm{Na}$ podstawie danych z GUS dotyczących informacji o sytuacji społeczno-gospodarczej kraju po pierwszej połowie 2016 roku.

15 T. Kowalak, Odwrócona hipoteka — zasady funkcjonowania i perspektywy wprowadzenia w Polsce, „Ruch Prawniczy, Ekonomiczny i Socjologiczny” 4, 2010, s. 151. 
W polskim ustawodawstwie nie było wcześniej jasnej, odrębnej regulacji w zakresie pozyskiwania dodatkowych środków pieniężnych przez osoby starsze (to jest osoby, które nabyły uprawnienia emerytalne). Wprawdzie w obrocie prawnym funkcjonowała i nadal funkcjonuje, także skierowana do osób starszych, instytucja tak zwanej renty dożywotniej, jednak nie ma właściwych przepisów w tym zakresie i zawieranie umów renty dożywotniej na podstawie ogólnych przepisów kodeksu cywilnego sprawiało, że interesy stron nie były dostatecznie chronione. Istota funkcjonującej dotąd umowy renty dożywotniej zawieranej między osobą fizyczną a firmą — instytucją finansową — sprowadza się do przeniesienia na tę firmę własności mieszkania - nieruchomości osoby fizycznej - w zamian za wypłacaną jej rentę dożywotnią, przy czym osoba taka zachowuje jednocześnie dożywotnie prawo zamieszkiwania w tym lokalu. Nie ma jednak przepisów regulujących choćby wymogi wobec firm uprawnionych do oferowania takich usług, stanowiących gwarancję ich wypłacalności (minimalny kapitał zakładowy) czy przepisów regulujących kwestie dotyczące sposobu określenia wysokości takiej renty, praw pozostałego przy życiu małżonka czy spadkobierców osoby, która uprzednio zawarła taką umowę. Celem zarówno renty dożywotniej, jak i hipoteki odwróconej jest zapewnienie dodatkowych źródeł dochodów przyszłym świadczeniobiorcom $\mathrm{w}$ zamian za przeniesienie posiadanego przez nich prawa własności nieruchomości. Zasadnicza różnica między tymi dwiema instytucjami polega na tym, że w przypadku odwróconego kredytu hipotecznego bank przejmuje nieruchomość dopiero po śmierci jej właściciela, i to pod warunkiem że jego spadkobiercy nie skorzystają z prawa wykupu takiej nieruchomości. Przy zawarciu umowy o rentę dożywotnią własność nieruchomości zostaje automatycznie (z dniem zawarcia takiej umowy) przeniesiona na firmę — spółkę oferującą tego typu usługi. Ze względu na takie czynniki, jak: moment przejścia własności nieruchomości, podmioty uprawnione do oferowania produktu, mechanizmy zabezpieczające interesy stron i spadkobierców osób korzystających z tych usług, hipoteka odwrócona jest niewątpliwie bezpieczniejsza z punktu widzenia interesów świadczeniobiorców ${ }^{16}$.

W udzielanym standardowo przez bank kredycie hipotecznym w momencie podpisania umowy kredytowej staje się on „właścicielem” nieruchomości kredytobiorcy. W miarę spłaty kredytu przez kredy tobiorcę zmniejsza się udział banku w nieruchomości. Po całkowitej spłacie kredytu nieruchomość staje się ponownie w całości własnością kredytobiorcy ${ }^{17}$.

W przypadku odwróconego kredytu hipotecznego sytuacja jest odwrotna. Bank, płacąc kredy tobiorcy raty kredytu, zwiększa swoje udziały w nieruchomości zabezpieczającej kredyt. W efekcie końcowym następuje przejęcie nierucho-

16 E. Bartkowiak, Hipoteka odwrócona, „Biuletyn Głównego Księgowego” 2016, nr 1, s. 58.

17 E. Twardowska, Odwrócony kredyt hipoteczny - blaski i cienie, „Studia Ekonomiczne Regionu Łódzkiego" 6, 2011, s. 233. 
mości przez bank, z którym kredytobiorca podpisał umowę. Odwrócony kredyt hipoteczny jest zatem ofertą skierowaną głównie do osób starszych posiadających nieruchomość, ale niemających jej komu przekazać i będących w potrzebie finansowej. Zgodnie z umową podpisaną z bankiem kredytobiorca może pozostać w swojej nieruchomości dożywotnio, jednakże jest zobowiązany do utrzymywania jej w niepogorszonym stanie oraz do dokonywania wszelkich niezbędnych opłat z nią związanych ${ }^{18}$.

Odpowiedzią na takie zapotrzebowanie jest odwrócony kredyt hipoteczny (reverse mortgage, home equity conversion mortgages). Jego istota sprowadza się do osiągania zysków przez gospodarstwa domowe z tytułu posiadanych aktywów. Tym samym odwrócona hipoteka pozwala na wyrównanie zapotrzebowania na aktywa przy jednoczesnym zachowaniu płynności finansowej ${ }^{19}$.

Tylko uporządkowany i uregulowany rynek może zapewnić profesjonalną obsługę konsumentów oraz ich bezpieczeństwo. Trzeba zauważyć, że jest to rynek newralgiczny zarówno z punktu widzenia samego produktu, jak i grupy osób, do której jest adresowany. Chodzi wszak o osoby starsze, czasami nawet w bardzo podeszłym wieku, które często mogą mieć problemy ze zrozumieniem mechanizmów przedmiotowego rynku i istoty oferowanych umów świadczeń dożywotnich. Dlatego zdaniem Prezesa UOKiK tak istotne jest, aby zostały uchwalone przepisy regulujące instytucje renty dożywotniej oraz odwróconego kredytu hipotecznego. Przyczyni się to do zagwarantowania bezpieczeństwa prawnego tym seniorom, którzy poszukują środków na zwiększenie swoich dochodów ${ }^{20}$.

Umowy zawierane w tym segmencie regulowane są przepisami ustawy z dnia 23 kwietnia 1964 roku - Kodeks cywilny (Dz.U. Nr 16, poz. 93 ze zm.). Praktyka rynkowa pokazała jednak, że część tych umów zawiera klauzule abuzywne. W tym kontekście ważne są doświadczenia Prezesa Urzędu Ochrony Konkurencji i Konsumentów związane z badaniem praktyk stosowanych przez podmioty, które pod nazwą ,hipoteki odwróconej” oferują w istocie umowę renty dożywotniej ${ }^{21}$.

\section{Beneficjenci odwróconej hipoteki}

Wysokość przyznanego kredytu uwarunkowana jest kilkoma czynnikami, między innymi wiekiem właściciela nieruchomości. Im kredytobiorca jest starszy, tym wyższą kwotę kredytu może uzyskać. Istotne jest również położenie nieruchomości oraz forma płatności. Kredyt udzielany jest jednakże w kwocie nie wyższej niż

18 A. Szelągowska, op. cit., s. 40.

19 M. Liberadzki, A. Palimąka, Bankowość hipoteczna, [w:] Współczesna bankowość, red. M. Zaleska, Warszawa 2007, s. 210.

${ }^{20}$ Zob. Raport z kontroli przedsiębiorców zawierających umowy świadczeń dożywotnich, UOKiK 2013, s. 79, https://www.uokik.gov.pl/download.php?plik=14028 (dostęp: 13.11.2018).

21 Wystąpienie Ireny Lipowicz, Rzecznika Praw Obywatelskich, skierowane do Ministra Gospodarki, 22.05.2013 r. 
50\% wartości nieruchomości, albowiem jego kwota wraz z odsetkami nie powinna przekroczyć wartości nieruchomości z przewidywanego dnia zakończenia trwania umowy, którym na ogół jest śmierć kredytobiorcy bądź jego małżonka. Zakończenie trwania umowy może również nastąpić w momencie opuszczenia przez kredytobiorcę obciążonej kredytem nieruchomości lub też w chwili zamiany zadłużenia na tradycyjny kredyt hipoteczny. Dzień zakończenia umowy jest również dniem, w którym rozpoczyna się spłata odsetek od kredytu. Spłata kredytu następuje poprzez sprzedaż nieruchomości. Jeżeli kwota uzyskana ze sprzedaży nieruchomości przekroczy kwotę zaciągniętego kredytu, wówczas nadwyżka przekazana zostanie rodzinie kredytobiorcy, jednakże jeśli kwota ta nie wystarczy na pokrycie kosztów, spadkobiercy nie będą zobowiązani do ich pokrycia ${ }^{22}$.

Produkt finansowy, jakim jest odwrócona hipoteka, jest adresowany przede wszystkim do osób powyżej 65 roku życia. Beneficjenci, którzy zdecydują się na to rozwiązanie, mogą kierować się elementami zalet płynących z takiego finansowania, a mianowicie niewykazywaniem zdolności kredytowej, comiesięcznym dożywotnim dopływem gotówki, uzyskaniem środków na spłatę zadłużenia lub inne wydatki. Oferenci mogą zyskać spokojne życie bez martwienia się o bieżące wydatki, opiekę medyczną i prawną oraz możliwość korzystania z długoterminowej opieki domowej. Otrzymują jednorazowy zastrzyk finansowy na wybrany cel, a przede wszystkim uzyskują gwarancję posiadania mieszkania lub domu do końca swego życia.

Głównym zabezpieczeniem jest ustanowiona hipoteka na nieruchomości, która powinna zabezpieczać całkowitą spłatę udzielonego kredytu wraz z należnymi odsetkami oraz innymi kosztami, a także ujawnienie w księdze wieczystej roszczenia o przeniesienie własności nieruchomości lub spółdzielczego własnościowego prawa do lokalu albo prawa użytkowania wieczystego. Natomiast wpisana hipoteka nie powinna przekraczać wartości rynkowej nieruchomości stanowiącej zabezpieczenie spłaty zaciągniętego zobowiązania.

Ustalenie wartości nieruchomości dokonywane jest przez biegłych rzeczoznawców majątkowych zgodnie z przepisami ustawy o gospodarce nieruchomościami, w których określenie wartości nieruchomości stanowiącej przedmiot prawa własności i innych praw do nieruchomości, które są lub mogą być przedmiotem obrotu, dokonuje się poprzez wycenę nieruchomości.

Należy pamiętać, że określona przez rzeczoznawcę wartość rynkowa nieruchomości nie przesądza o wysokości udzielonego produktu finansowego, stanowi jedynie podstawę do ustalenia maksymalnej wysokości ustanowionej hipoteki.

Kwota przyznanego świadczenia zależy nie tylko od wartości nieruchomości (obecnej i spodziewanej przyszłej) czy kosztów kredytu, lecz także od płci i wieku właściciela oraz niekiedy stanu jego zdrowia. Najczęściej będzie się zawierała w przedziale od $70 \%$ do nawet jedynie $30 \%$ wartości nieruchomości.

22 A. Szelągowska, op. cit., s. 40, 86. 
Tab. 1. Długość życia w latach według płci

\begin{tabular}{|c|c|c|}
\hline $\begin{array}{c}\text { Wiek } \\
\text { (lata) }\end{array}$ & $\begin{array}{c}\text { Przewidywana długość } \\
\text { życia mężczyzn (lata) }\end{array}$ & $\begin{array}{c}\text { Przewidywana długość } \\
\text { życia kobiet (lata) }\end{array}$ \\
\hline 65 & 16 & 20 \\
\hline 70 & 13 & 16 \\
\hline 75 & 10 & 13 \\
\hline 80 & 8 & 9 \\
\hline 85 & 6 & 7 \\
\hline 90 & 4 & 5 \\
\hline
\end{tabular}

Źródło: opracowanie własne.

Jakie kwoty świadczenia uzyskamy od Funduszu Hipotecznego, zakładając wartość rynkowej nieruchomości wycenionej na kwotę 300 tys. zł?

Tab. 2. Przykładowe kwoty wypłaconego comiesięcznie świadczenia

\begin{tabular}{|c|c|c|}
\hline $\begin{array}{r}\text { Wiek } \\
\text { (lata) }\end{array}$ & Dla mężczyzn (zł) & Dla kobiet (zł) \\
\hline 65 & 600 & 450 \\
\hline 70 & 800 & 600 \\
\hline 75 & 1200 & 900 \\
\hline 80 & 1800 & 1800 \\
\hline 85 & 2400 & 2200 \\
\hline 90 & 2400 & 2200 \\
\hline
\end{tabular}

Źródło: opracowanie własne.

Tab. 3. Wysokość świadczenia a wartość nieruchomości

\begin{tabular}{|c|c|c|c|c|}
\hline $\begin{array}{c}\text { Wiek } \\
\text { (lata) }\end{array}$ & $\begin{array}{c}\text { Wypłata } \\
\text { comiesięcznego } \\
\text { świadczenia dla } \\
\text { mężczyzn (zł) }\end{array}$ & $\begin{array}{c}\text { Przewidywana } \\
\text { długość życia } \\
\text { mężczyzn (lata) }\end{array}$ & $\begin{array}{c}\text { Przewidywana } \\
\text { kwota wypłaty } \\
\text { świadczenia (zł) }\end{array}$ & $\begin{array}{c}\text { Procentowy udział } \\
\text { wypłaty w wartości } \\
\text { nieruchomości }\end{array}$ \\
\hline 65 & 600 & 16 & 115200 & 38 \\
\hline 70 & 800 & 13 & 124800 & 42 \\
\hline 75 & 1200 & 10 & 144000 & 48 \\
\hline 80 & 1800 & 8 & 172800 & 58 \\
\hline 85 & 2400 & 6 & 172800 & 58 \\
\hline 90 & 2400 & 4 & 115200 & 38 \\
\hline
\end{tabular}

Źródło: opracowanie własne. 
Tab. 4. Wysokość świadczenia a wartość nieruchomości

\begin{tabular}{|c|c|c|c|c|}
\hline $\begin{array}{c}\text { Wiek } \\
\text { (lata) }\end{array}$ & $\begin{array}{c}\text { Wypłata comie- } \\
\text { sięcznego świad- } \\
\text { czenia dla kobiet } \\
\text { (zł) }\end{array}$ & $\begin{array}{c}\text { Przewidywana } \\
\text { długość życia } \\
\text { kobiet (lata) }\end{array}$ & $\begin{array}{c}\text { Przewidywana } \\
\text { kwota wypłaty } \\
\text { świadczenia (zł) }\end{array}$ & $\begin{array}{c}\text { Procentowy udział } \\
\text { wypłaty w wartości } \\
\text { nieruchomości }\end{array}$ \\
\hline 65 & 450 & 20 & 108000 & 36 \\
\hline 70 & 600 & 16 & 115200 & 38 \\
\hline 75 & 900 & 13 & 140400 & 47 \\
\hline 80 & 1800 & 9 & 194400 & 65 \\
\hline 85 & 2200 & 7 & 184800 & 62 \\
\hline 90 & 2200 & 5 & 132000 & 44 \\
\hline
\end{tabular}

Źródło: opracowanie własne.

Tab. 5. Procentowy udział wypłaty w wartości nieruchomości

\begin{tabular}{|c|c|c|}
\hline $\begin{array}{c}\text { Wiek } \\
\text { (lata) }\end{array}$ & Dla mężczyzn & Dla kobiet \\
\hline 65 & 38 & 36 \\
\hline 70 & 42 & 38 \\
\hline 75 & 48 & 47 \\
\hline 80 & 58 & 65 \\
\hline 85 & 58 & 62 \\
\hline 90 & 38 & 44 \\
\hline
\end{tabular}

Źródło: opracowanie własne.

Przyjmując, że oprocentowanie udzielonego produktu finansowego będzie sumą współczynnika WIBOR 3M na poziomie 1,72\% i marży podmiotu finansowego na poziomie $5 \%$, to całkowite oprocentowanie świadczenia wyniesie $6,72 \%$.

Tab. 6. Potencjalne koszy odwróconej hipoteki

\begin{tabular}{|l|c|c|}
\cline { 2 - 3 } \multicolumn{1}{c|}{} & Mężczyzna — 75 lat & Kobieta — 75 lat \\
\hline Pozostała długość życia & 10 & 13 \\
\hline Wypłacone świadczenie & $144000 \mathrm{zł}$ & $140400 \mathrm{zł}$ \\
\hline Odsetki od kredytu liczone od zmiany salda & $48787 \mathrm{zł}$ & $61720 \mathrm{zł}$ \\
\hline Prowizja za udzielenie kredytu — 5\% & $7200 \mathrm{zł}$ & $7020 \mathrm{zł}$ \\
\hline $\begin{array}{l}\text { Opłata za przygotowanie i rozpatrzenie wniosku } \\
\text { kredytowego —-2,5\% }\end{array}$ & $3600 \mathrm{zł}$ & $3510 \mathrm{zł}$ \\
\hline Koszt wyceny nieruchomości lub lokalu & $1000 \mathrm{zł}$ & $1000 \mathrm{zł}$ \\
\hline
\end{tabular}




\begin{tabular}{|l|r|r|}
\hline $\begin{array}{l}\text { Koszt monitorowania wartości nieruchomości } \\
\text { lub lokalu }-1000 \mathrm{zł} / \text { rok }\end{array}$ & $10000 \mathrm{zł}$ & $13000 \mathrm{zł}$ \\
\hline Razem: & $214587 \mathrm{zł}$ & $226650 \mathrm{zł}$ \\
\hline Ryzyko zmiany wartości nieruchomości $-10 \%$ & $21459 \mathrm{zł}$ & $22665 \mathrm{zł}$ \\
\hline SUMA: & $236046 \mathrm{zl}$ & $249315 \mathrm{zł}$ \\
\hline
\end{tabular}

Źródło: opracowanie własne.

Tab. 7. Koszt świadczenia a wartość nieruchomości

\begin{tabular}{|l|c|c|}
\cline { 2 - 3 } \multicolumn{1}{c|}{} & Mężczyzna — 75 lat & Kobieta -75 lat \\
\hline Wartość nieruchomości & $300000 \mathrm{zł}$ & $300000 \mathrm{zł}$ \\
\hline Przewidywany koszt produktu finansowego & $236046 \mathrm{zł}$ & $249315 \mathrm{zł}$ \\
\hline $\begin{array}{l}\text { Procentowy udział produktu finansowego } \\
\text { w wartości nieruchomości }\end{array}$ & 78,68 & 83,11 \\
\hline
\end{tabular}

Źródło: opracowanie własne.

Mając to na względzie, przewidywany koszt produktu finansowego będzie zrównany z wysokością ustanowionej hipoteki, która będzie mniejsza od wartości rynkowej nieruchomości.

Tab. 8. Udział produktu finansowego w wartości nieruchomości

\begin{tabular}{|l|c|c|}
\cline { 2 - 3 } \multicolumn{1}{c|}{} & Mężczyzna - 75 lat & Kobieta - 75 lat \\
\hline Wartość nieruchomości & $300000 \mathrm{zł}$ & $300000 \mathrm{zł}$ \\
\hline $\begin{array}{l}\text { Procentowy udział produktu finansowego } \\
\text { w wartości nieruchomości }\end{array}$ & 78,68 & 83,11 \\
\hline
\end{tabular}

Źródło: opracowanie własne.

Pomimo roszczenia banku o przeniesienie własności nieruchomości prawa na jego rzecz z dniem wymagalności kredytu spadkobiercy kredytobiorcy mogą zachować prawo do nieruchomości, pod warunkiem że w terminie dwunastu miesięcy od dnia śmierci kredytobiorcy lub ostatniego z kredytobiorców dokonają całkowitej spłaty należności. W przeciwnym razie nieruchomość przejdzie na własność banku, z tym zastrzeżeniem, że jeżeli jej wartość przekroczy sumę należności wobec banku, ten wypłaci nadwyżkę spadkobiercom. Z kolei jeśli wartość nieruchomości nie pokryje całej należności wobec banku, ten nie będzie mógł wobec spadkobierców dochodzić roszczeń z tego tytułu. Z punktu widzenia stron umowy odwróconego kredytu hipotecznego istotne znaczenie ma dokładność wyceny rynkowej nieruchomości i ustalona na jej podstawie wysokość kredytu przekładająca się na wysokość rat. Istnieje bowiem zagrożenie, że wypłata rat 
umówionego kredytu może ustać jeszcze przed śmiercią kredytobiorcy. Z tego względu ważny jest powód zawierania umowy odwróconego kredytu hipotecznego (czy powodem tym jest chęć uzyskiwania przez kredytobiorcę comiesięcznych dodatkowych środków pieniężnych aż do śmierci, czy pozyskanie jednorazowo określonej kwoty pieniężnej). Ponadto należy mieć na uwadze konieczność zachowania nieruchomości przez kredytobiorcę w stanie niepogorszonym. W praktyce oznacza to konieczność wydatkowania przez kredytobiorcę określonych środków finansowych na niezbędne remonty (na przykład wymiana rynien, naprawa dachu) tak, by wartość nieruchomości nie spadła z winy kredytobiorcy (z powodu jego zaniedbania, zaniechania). Ma to znaczenie z tego względu, że jeżeli wartość nieruchomości spadnie z winy kredytobiorcy, bank będzie mieć wówczas prawo do zaspokojenia swoich roszczeń także z innych składników majątkowych kredytobiorcy, a nie tylko z tej nieruchomości stanowiącej zabezpieczenie kredytu ${ }^{23}$.

Wobec wzrastającej długości życia ludzkiego i zwiększających się wydatków publicznych związanych z wypłatą emerytur odwrócona hipoteka jest postrzegana jako rozwiązanie wspierające przytłaczające koszty starzejących się społeczeństw ${ }^{24}$. Ma zatem, pomimo ciągle jeszcze bardzo małego udziału w rynku, znaczne perspektywy rozwoju. Usługi tego rodzaju wprowadzane są w krajach, w których dotychczas, z przyczyn kulturowych, opieka nad osobami starszymi opierała się raczej na zobowiązaniach rodzinnych niż na państwowych systemach zabezpieczenia społecznego. Przykładem są kraje Azji Wschodniej, na przykład Japonia, Singapur, Korea Południowa czy Chiny ${ }^{25}$.

Odwrócony kredyt hipoteczny popularyzowany jest jako innowacyjny produkt finansowy, korzystnie stymulujący wzrost gospodarki, poprawiający jakość życia seniorów i pozwalający na odciążenie dzieci ${ }^{26}$.

Największą korzyścią z funkcjonowania usług typu equity release jest możliwość pozyskania przez osoby w starszym wieku dodatkowych środków finansowych z prawem pozostania we własnym domu i uniezależnienie się od finansowego wsparcia rodziny. Finansowe konsekwencje tendencji demograficznych powodują, że odwrócony kredyt hipoteczny może stać się coraz częstszym źródłem dodatkowego dochodu emerytów zarówno w Polsce, jak i w innych krajach. Ponadto w Polsce emerytury będą relatywnie malały, istotne jest więc umożliwienie pozyskania dodatkowych środków, aby standard życia na emeryturze nie uległ gwałtownemu obniżeniu. W związku z tym ważne jest zapewnienie regulacji prawnych pozwalających na bezpieczne funkcjonowanie tego rodzaju usług. Uchwalenie

23 Zob. E. Bartkowiak, op. cit., s. 58.

24 A. Gotman, Towards the end of bequest? The life cycle hypothesis sold to seniors. Critical reflections on the reverse mortgage financial fashion, „Civitas” 11, 2011, nr 1, s. 100.

25 J. Doling, R. Ronald, Meeting the income needs of older people in East Asia: using housing equity, „Ageing \& Society” 32, 2012, s. 471-490.

26 J. Zhao, On Barriers and Countermeasures for China Implementing Reverse Home Mortgage Loans, „Asian Social Science” 5, 2009, nr 3, s. 168. 
ustawy umożliwiło wprowadzenie usługi odwróconego kredytu hipotecznego na polski rynek finansowy, jednak nie zobowiązuje banków do podjęcia działalności w tym zakresie. Rozwiązania zaproponowane w ustawie o odwróconym kredycie hipotecznym nie są wzorowane na żadnym konkretnym państwie. Można jednak dostrzec analogię niektórych przyjętych rozwiązań do już funkcjonujących w innych krajach UE, na przykład do regulacji brytyjskich w odniesieniu do nałożonego na kredytodawcę obowiązku przedstawiania określonego zestawu informacji na poszczególnych etapach zawierania umowy. Tego rodzaju wymogi pozwalają na zapewnienie jak najlepszej ochrony potencjalnego kredytobiorcy i dostosowanie usługi do jego indywidualnych potrzeb ${ }^{27}$.

Dlatego też bardzo ważny jest rozwój dodatkowych form zabezpieczenia emerytalnego. Jednakże zależy on od wielu czynników. Należy wyróżnić tutaj między innymi zamożność społeczeństwa, rozwój rynku finansowego i jego dostępność, poziom wiedzy finansowej obywateli i zdolność podejmowania przez nich decyzji w warunkach ryzyka, zaangażowanie państwa oraz przedsiębiorstw w tworzeniu elastycznych i przejrzystych produktów odgrywających rolę zabezpieczenia emerytalnego oraz zachęty podatkowe zarówno dla osób korzystających, jak i przedsiębiorstw tworzących stosowne produkty zabezpieczenia emerytalnego ${ }^{28}$.

\section{Zakończenie}

W przedstawionym artykule autor ukazał najistotniejsze kwestie związane z zagrożeniami, niebezpieczeństwem, a także możliwościami, jakie oferuje odwrócona hipoteka. Dzięki rzetelnej analizie, po wcześniejszym zrozumieniu opisanych w artykule czynników, przy jednoczesnym uwzględnieniu praktycznego doświadczenia i zaobserwowaniu zasad funkcjonowania gospodarki wolnorynkowej, powstanie oszacowany model analizy ekonomicznej, który może przewidzieć przyszły trend, do jakiego może dojść w realizacji odwróconego kredytu hipotecznego.

\section{Bibliografia}

Bartkowiak E., Hipoteka odwrócona, „Biuletyn Głównego Księgowego” 2016, nr 1.

Bączyk M., Umowy w zakresie czynności bankowych, [w:] System prawa handlowego, t. 5. Prawo umów handlowych, red. S. Włodyka, Warszawa, 2014.

Czech T., Odwrócony kredyt hipoteczny. Komentarz, LEX, Warszawa 2015.

Doling J., Ronald R., Meeting the income needs of older people in East Asia: using housing equity, „Ageing \& Society” 32, 2012.

27 M. Grzeszczuk-Gniewek, op. cit., s. 320.

28 J. Rutecka, Dodatkowe zabezpieczenie emerytalne - charakterystyka i czynniki rozwoju, [w:] Ubezpieczenia wobec wyzwań XXI wieku, red. W. Ronka-Chmielowiec, „Prace Naukowe UE” nr 342, Wrocław 2014, s. 262. 
Golinowska S., ,Srebrna gospodarka” i miejsce w niej sektora zdrowotnego. Koncepcja i regionalne przyktady zastosowania, „Zdrowie Publiczne i Zarządzanie” 2011, t. 9, nr 1.

Gotman A., Towards the end of bequest? The life cycle hypothesis sold to seniors. Critical reflections on the reverse mortgage financial fashion, „Civitas” 11, 2011, $\mathrm{nr} 1$.

Grzeszczuk-Gniewek M., Odwrócony kredyt hipoteczny, „Państwo i Społeczeństwo” 2 marzeckwiecień 2015.

Kardas M., Inteligentne specjalizacje — (nowa) koncepcja polityki innowacyjnej, „Optimum. Studia Ekonomiczne" 2001, nr 2 (50).

Kowalak T., Odwrócona hipoteka - zasady funkcjonowania i perspektywy wprowadzenia w Polsce, „Ruch Prawniczy, Ekonomiczny i Socjologiczny” 4, 2010.

Nazarko Ł., Inteligentne specjalizacje polskich regionów — przyczynek do ewaluacji, „Przedsiębiorczość i Zarządzanie" 15, 2014, z. 8, cz. 1.

Rudnicka M., Surdej A., Gospodarka senioralna. Nowy sektor gospodarki narodowej w Polsce, Warszawa 2013.

Starzenie się ludności Polski - między demografia a gerontologia społeczna, red. J.T. Kowaleski, P. Szukalski, Łodź 2008.

Szelągowska A., Wspótczesna bankowość hipoteczna, Warszawa 2010.

Szukalski P., Solidarność pokoleń. Dylematy relacji międzypokoleniowych, Łódź 2012.

Twardowska E., Odwrócony kredyt hipoteczny — blaski i cienie, „Studia Ekonomiczne Regionu Łódzkiego" 6, 2011.

Ubezpieczenia wobec wyzwań XXI wieku, red. W. Ronka-Chmielowiec, „Prace Naukowe Uniwersytetu Ekonomicznego" nr 342, Wrocław 2014.

Urbaniak B., Gładzicka-Janowska A., Żyra J., Kaliszczak L., Piekutowska A., Rollnik-Sadowska E., Sobolewska-Poniedziałek E., Niewiadomska A., Gagacka M., Socjoekonomika starzenia się wspótczesnych społeczeństw, Warszawa 2015.

Współczesna bankowość, red. M. Zaleska, Warszawa 2007.

Zhao J., On Barriers and Countermeasures for China Implementing Reverse Home Mortgage Loans, „Asian Social Science” 5, 2009, nr 3.

\section{Equity release dedicated product for the "silver economy"}

\section{Summary}

The present work is a presentation of equity release dedicated product for the "silver economy". Due to the nature of the paper main research method is an objective analysis of the legal provisions relating to the reverse mortgage as well as a critical analysis of comparative literature and economic elements related to the financial product which is the reverse mortgage. A proper analysis and understanding of the factors described above coupled with appropriate application of these factors to everyday rules of market functioning allows us to anticipate upcoming trends present in the free market economy reverse mortgage. 